\title{
The Concept of Holistic and Sustainable Development Based on Harmony
}

\author{
By Nickolay Suvorov ${ }^{1}$, Iryna Suvorova ${ }^{2}$
}

\begin{abstract}
Based on the use of the Greek language and the concepts of ethics, philosophy and higher mathematics, the LOGOS HARMONY has been developed.

LOGOS HARMONY allows establishing the following: the basic constituents of a proper world outlook - belief, spirituality and harmony; the quality of energy of inner and outer interaction between people based on harmony-morality and harmony-ethics;

the sense and profound content of moral-ethical rules, laws and canons;

scientifically substantiated criteria of quality and perfection of human personality;

the concept of cosmotheory - the theory of development of humans and the Universe;

the sense of the word "prosperity" as aspiration to the summit and highest point as a unification of energy and high ethics and high morality in a single harmonious unity.

It has been proved mathematically that the underpinning of development of a Human Being and Humanity is harmonised energy, and the energy of harmony-peace, and the energy of harmony-love. HARMONY is the basis of holistic sustainable development of nations and the human civilisation.
\end{abstract}

Keywords: Cosmotheory, energy, harmony, perfection, harmony-morality, harmony-ethics, Orthogonality.

\section{Introduction. Addressing the Problem of Sustainable Development}

Modern concepts of sustainable development are based on changing radically and fundamentally the quality of the most significant kinds of matter used in a variety of human activities. With the established terminology, radical and fundamental quality changes are called innovation ones.

To solve the problem stated, the development model should be focused to achieving economic effectiveness. Thereat it is considered that economic effectiveness is a panacea for all woes, capable of paving the way to universal well-being. However, real life shows that if economic growth is based exclusively on the quality and quantity indicators of matter, it will inevitably lead not only to unstable development, but also to self-destruction and self-liquidation of the entire human environment [1].

The strategy of holistic sustainable development cannot be developed without a scientific substantiation of the fundamentals, principles and philosophy of development [2].

However, the fundamentals, principles and philosophy of development cannot be substantiated also without a clear and distinct understanding of the essence of development-evolution of human beings, society and the nation, which shape the economy, politics and all social environment superstructures.

People have always been the source of the entire diversity of life.

During the $20^{\text {th }}$ and $21^{\text {st }}$ centuries, many persons have found and acknowledged that the World and Universe are a unity, integration and union of all kinds of energy comprising an indissoluble 
whole. Likewise, a human being is not only a multitude of cells, organs and intricate systems of physical nature, but also a container of subtle energy, including the energy of the mind and spirit located in the physical body.

From the standpoint of advanced achievements of many new sciences in the $20^{\text {th }}$ century, humans, society and a nation can be considered complex composite energy-information forms, viz. entities, structures, systems and energy-information fields [1 - 4].

Energy is a universal substance underlying the existence and development of the World, and hence, of humans. Energy is the sole substance of all being. All things surrounding us and everything we are composed of is energy of various density and vibration frequencies. Information is also energy, but of a special subtly organised kind.

Recall that life is an ensemble of all kinds of energy in their continuity. In physical space, energy and information have one sign, the plus. In the Subtle World, the world of emotions and thoughts, energy and information have both opposite signs (plus and minus). The World and Antiworld are formed by energy having opposite signs ("+" and "-").

Energy is the substance that unites ALL, seemingly unformation, and helps solve issues considered irresolvable. ALL is reduced to the quantity and quality of energy, and to the energy of inner and external interaction of people. By virtue of the aforesaid, the energy-information, energy, bioenergy-information and the bioenergy approach to investigating different objects, entities, structures, systems and, as a whole, energy-information forms of different nature, including humans, is consistent. The energy-information approach allows using both analysis and synthesis methods established in physical-mathematical and engineering sciences for forming new anthropological energy-information images, viz. humans, society and nation.

Hence, energy-information analysis establishes the trueness of the basic philosophical principle that energy is primary and matter is secondary. This statement calls for developing a new concept of development-evolution to scientifically substantiate the methods and system of shaping (bringing up and educating) a new human being, a person of the future who would ensure holistic and sustainable development.

\section{A New Concept of Human Development-Evolution}

Ancient Greeks said:

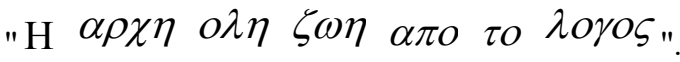

This means that the basis and primary source of all life is LOGOS. LOGOS is a word, but LOGOS primarily means reason and the ability to think.

At the current stage of development of human beings and humanity, LOGOS initiates, on the one hand, the mission of popularising God's Word, and on the other hand, it presents the challenge of synthesising science, philosophy and religion into a unified theory of Man and for Man [2].

Presently, advanced researchers have understood the necessity of uniting science and religion in the hope that such a union would help humanity emerge from a major crisis, namely, the morality and ethical one, in which civilisation has found itself.

However, even the most sound and "inviolable" union can be destroyed if an intrinsically true idea of unity is absent. Hence, it is necessary to articulate the idea of forming not a union but rather an organic inseparable fusion, a harmony of science and religion.

Based on integrating latest achievements of science, philosophy and religion, a unified holistic doctrine - the theory of development of humans or Cosmotheory - can be create [2, $5-7]$.

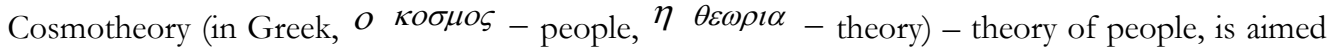
at forming the following: 
- a perfect human $\alpha \rho \imath \sigma \tau \sigma \varsigma \alpha v \theta \rho \omega \pi \sigma \varsigma$ - aristos antropos ( $\alpha \rho \imath \sigma \tau o \varsigma$ - perfect, o $\alpha v \theta \rho \omega \pi o \varsigma$ - human);

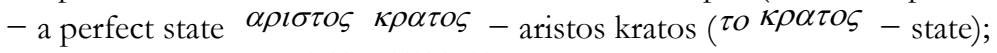

- a perfect society $\eta \alpha \rho \imath \sigma \tau о \kappa \rho \alpha \pi \alpha$ - aristokratia.

In the literature [2, $5-8]$, the following energy and ethical categories were included as the basic components of the new concept of human development-evolution:

- energy and information;

- the quality and amount of energy of internal and external interaction of energy-information

forms and systems of different nature;

- inner and external harmony;

- harmony-morality and harmony-ethics;

- harmony-peace, balance and equilibrium;

- harmony-love;

- personal harmony;

- collective (group) harmony;

- full harmony;

- good and evil;

- transfiguration (metamorphosis);

- perfection;

- a right worldview;

- cosmotheory - the theory of development of people and the Universe.

Among all the constituents of the new development concept, a special role is assigned to the worldwiew. The Greek language offers an in-depth understanding of the worldview concept. In

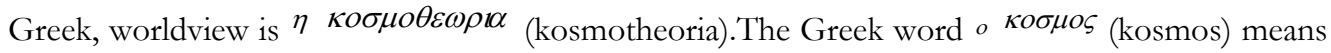
the following: Cosmos, the Universe, the World, society, demos and humans. Hence, cosmotheory is not simply an view of how the World is built. It is a theory of development of humans and the Universe. Humans (cosmos) and the Universe (Cosmos) have the same name. This is a manifestation of the wisdom of the people of Ancient Greece.

The Worldview is the theory of development of a human being and people, and this predetermines the strict requirements to the problem being investigated. Moreover, the theory of development of humans and the Universe, as to its concept and intention, and by its definition, should be unified, integrated, holistic and systemic. Cosmotheory has not been developed yet as a consistent theory and science, and this presents a major challenge. One can speak only of the concepts of cosmotheory and its fundamental tenets. However, by developing the theoretical basics of harmony one can substantiate scientifically the fundamental components of a true worldview. They include belief, spirituality and harmony. These components are the underpinning, the foundation of cosmotheory as a whole. As cosmotheory develops, the number of basic components can increase to any amount, even to infinity.

The knowledge of belief, spirituality and harmony should be the most profound and extensive one. This will help understand the substance of a true worldview, a new philosophy of bringing up and educating, and the philosophy of treatment-healing. The basic components of a true worldview come laden with huge ethical and energy-information significance. This becomes evident as one gains insight into their substance and form.

All the basic components of cosmotheory are essential and important, though special emphasis should be placed on harmony.

Harmony is the Great Cosmic Law of Development, the Law of the CREATOR-ABSOLUTE, the Law of GOD, and the principle and technology of creation.

Harmony is the "building block" for the entire edifice of Cosmotheory. Clearly, the time is ripe to create the theory of harmony or its fundamentals. Harmony has many facets, gradations and nuances, and they all are of utmost importance, especially for shaping high ethical standards of 
human relations.

The knowledge of harmony is vital for assessing the quality and perfection of complex composite energy-information entities and structures, including the assessment of the quality and perfection of man, a collective, a group of people, society, and a nation.

Cosmotheory and a true worldview are the theoretical basis for forming the image of a new human, a human possessing a new quality of interaction energy. Thereat harmony is a powerful driving factor in the development of a true worldview and cosmotheory as a whole.

In $[2,4-6]$, harmony has been shown to be a criterion of optimality, perfection, and high quality of energy with which energy-information forms and systems of various nature interact. That will suffice to effect radical changes in a human's diverse life.

\section{Orthogonality - the mathematical rule of harmony}

The authors have investigated harmony in detail in $[1,2,5-8]$.

For the first time ever, the concept of harmony has been developed from an ethical, philosophical and mathematical perspective, and the quantitative measure of harmony has been defined. Harmony has been computed in practice for simple and complex technical energy-information forms and systems, as well as for live organisms [9].

The scientific substantiation of harmony is capable of effecting drastic changes in many areas of life of a separate human and of all people. Moreover, it will help solve the problem of shaping a human personality of high quality and perfection.

From the scientific standpoint, the categories of "quality", "optimality" and "perfection" have been formulated and defined quantitatively. Harmony has been proved scientifically to be the universal criterion of the quality of inner and external interaction energy, the criterion of optimality and the criterion of perfection of energy-information forms and systems of different nature.

A perfect human - $\alpha \rho \imath \sigma \tau \sigma \varsigma \alpha v \theta \rho \omega \pi o \varsigma$ can and should become a reality because harmony as the criterion (measure) of perfection has been substantiated.

Harmony is the "foothold" that will help change and drastically transform homo sapiens.

Harmony, which defines the quality and perfection of energy-information forms and systems, is written in mathematical terms as two functionals:

- the autocorrelation coefficient of real and model (or ideal) energy-information forms $-\rho$;

- the cross-correlation coefficient for energy-information forms $-r$.

Here, autocorrelation coefficient ${ }^{\rho}$ determines inner harmony and cross-correlation coefficient $r$ determines external harmony.

The autocorrelation coefficient is defined as

$\rho=\frac{1}{E_{0}} \int_{\{t\}} S_{i}(t, C) S_{\ni i}(t, C) d t \quad i=\overline{1, M}$.

The cross-correlation coefficient is defined as

$r=\frac{1}{E_{0}} \int_{\{t\}} S_{i}(t, C) S_{j}(t, C) d t \quad i \neq j, i, j=\overline{1, M}$.

The inner interaction energy - the autocorrelation of a real energy-information form with a model one - is defined as follows

$$
E=\int_{\{t\}} S_{i}(t, C) S_{\ni i}(t, C) d t=E_{0} \rho \quad i=\overline{1, M} .
$$

The energy of external interaction - the cross-correlation of different energy-information forms with each other - is defined as follows 


$$
E=\int_{\{t\}} S_{i}(t, C) S_{j}(t, C) d t=E_{0} r \quad, \quad i \neq j, i, j=\overline{1, M} .
$$

Here $\left\{S_{i}(t, C)\right\}_{i=1}^{M}$ is the multitude of real energy-information images, $M$ is set dimensionality, $\left\{S_{3 i}(t, C)\right\}_{i=1}^{M}$ is set of model energy-information images, $C$ is energy parameter, a multidimensional quantity (vector), $E_{0}=\int_{\{t\}} S^{2}(t, C) d t=\int_{\{t\}} S_{3}^{2}(t, C) d t$ is the own energy of images, and $\{t\}$ is domain of existence of parameter $t$.

Autocorrelation coefficient $\rho$ defines the following:

- the quality and quantity value of inner harmony;

- the quality and quantity value of the energy of inner interaction between the real and model form.

Cross-correlation coefficient $r$ defines the following:

- the quality and quantity value of external harmony;

- the quality and quantity value of the energy of external interaction between different forms.

In mathematical terms, the supreme level of the ethical and moral perfection of a human personality is determined by the orthogonality condition. Upon achieving this condition:

- the autocorrelation coefficient, determining harmony-morality, achieves a maximum of $\rho=1$ with harmony-love;

- energy of inner interaction - autocorrelation achieves a maximum positive value of $E=E_{0} \rho=E_{0}$ and the highest qualitative value with harmony-love;

- the cross-correlation coefficient, determining harmony-ethics, achieves a minimum value of $r=0$ with harmony-peace;

- energy of external interaction - cross-correlation achieves the minimal value of $E=E_{0} r=0$ energy of peace, balance and equilibrium.

Hence, the ethical and moral perfection of a human is the process of one's potential achievement of the ethical categories of peace and love.

This is the substance and essence of a perfect human.

Only the new human is potentially capable of ensuring holistic sustainable development and the prosperity of humans, the nation and civilisation.

The Greek language gives an explanation of the essential meaning of the word "prosperity".

Prosperity $-\eta \alpha \kappa \mu \eta$ (akme):

- the summit, the highest point, the climax;

- the peak, the razor edge, the "golden mean"; $\alpha \kappa \mu \alpha ı \varsigma$ (akmaios):

- flourishing, thriving, exuberant, buoyant, and vigorous;

- being at a high level; $\alpha \kappa \mu \alpha ı$ (akmaio):

- high ethics spirit;

- high morality.

Hence, flourishing is the drive to reach the summit, the peak, a union of energy, and power, and high ethics and high morality into a unified and harmonic whole.

A high level of ethics and morality in anthropological entities gives rise to the condition of orthogonality, which describes ideal harmonised images.

\section{Harmony-Morality and Harmony-Ethics}

Harmony-morality is inner harmony, the harmony of a human being with a model, an ideal and God.

Different levels of inner harmony of harmony-morality yield various quantitative values of human 
quality and perfection.

The supreme level of inner harmony of harmony-morality is love. Harmony-love ensures the supreme quality of human interaction with God. In so doing, it forms the supreme personal qualities, the qualities of creativity and creation.

Quantitatively, autocorrelation coefficient $\rho$ determines the value of the quality of inner interaction energy and the level of human perfection.

When the autocorrelation coefficient reaches the value of $\rho=1$, one can consider that an morality resonance has been achieved between a human and God.

With a morality resonance with God, the inner harmony of a human is transformed to harmonylove to form the supreme inner quality and perfection of a human.

With resonance, the level of inner interaction energy $E$ quantitatively achieves the maximum value $E=E_{0} \rho=E_{0}$, where $E_{0}$ is own energy of the energy-information image.

Hence, inner harmony, harmony-morality is potentially capable of ensuring, with resonance, the maximum coefficient of beneficial usage of the energy of a human's inner interaction with God, with an ultimate exclusion of energy losses.

Maximising inner harmony results in morality self-perfection of the human personality.

Harmony-ethics is external harmony. The law of the CREATOR defines the substance of external harmony.

The CREATOR's law of harmony, the law of unity and harmony of opposites, or the Law of Conservation of Harmony is stated as follows: the total amount of energy with the plus $(+)$ sign and the minus ( - ) one should be balanced and equalised.

In mathematical terms, the equality "+" + "-" =0 should hold. This means that the crosscorrelation coefficient for different energy-information forms should equal zero $r="+"+"-"$ = zero.

The energy of external interaction of forms, according to the requirements of the law of the CREATOR, should be minimal and, ultimately, equal zero $E=E_{0} r \rightarrow 0$.

Hence, structural and systemic disturbances, emotional and informational "junk" between energyinformation forms, and "nonorthogonality noise" should be absent.

There should be no self-destruction and self-liquidation due to disturbing harmony with the CREATOR, primarily, the energy balance and equilibrium.

The precept "Do no harm!" follows the law of harmony of the CREATOR. This is the source and basis of the ethical principles of human interaction.

Harmony-ethics characterises the quality of energy of external interaction of humans with each other and of a human being with the environment.

An ideal external harmony implies peace (calm), consent and mutual understanding.

Peace is the supreme ethical category of harmony-ethics.

Maximisation of external harmony leads to ethical perfection of humans.

\section{Conclusion}

Harmony is a universal criterion of perfection, inner and external, and morality and ethics. Hence, it is fair to say that harmony is the basis of holistic sustainable development of nations and the human civilisation. 


\section{References}

Nikolay Suvorov and Irina Suvorova. Scientific basics of forming human quality and perfection to ensure holistic sustained development. European Journal of Sustainable Development (2015), 4, 1, 149160. Doi: $10.14207 /$ ejsd.2015.v4n1p149. ISSN: 2239-5938.

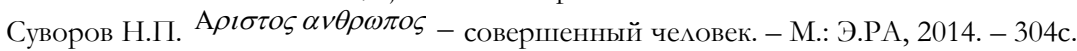

Суворов Н.П. Сигналы в системах каналообразования и проводной связи. Учебное пособие, ИзАательство ХВВКУ, 1979. - 144c.

Суворов Н.П. Системы каналообразования и проводной связи. Учебник, Издательство МО СССР, 1991. - 412c.

Суворов Н. П., Суворова И.Г. Введение в космотеорию Части I - VII. - Харьков: Издательство Шуст А.И., 2001, 2002, 2003. - 172с.

Суворов Н.П. Гармонический анализ как способ познания человека//Медична гіАрологія та реабілітація. - 2003. - 1, №2 -С.100 -107; - 2004. - 2, №1 -С.91-102; - 2004. - 2, №2 -С.70 -79; - 2008. - 6, №4 -C.109 - 118; - 2009. - 7, №1 -C.103 - 109; - 2009. - 7, №4 -C.111 $-124 ;-2010 .-8$, №1 -C.24 - 30; - 2010. - 8, №4 -C.73 - 78.

Суворов Н.П. and Суворова И.Г. Концепции космотеории// Медична гіАрологія та реабілітація. 2004. - 2, №3 -C.58 -73; - 2004. - 2, №4 -C. $84-95 ;-2005$. - 3, №1 -C.81 - 96; - 2005. - 3, №3 -C.63 - 87; - 2007. - 5, №1 -C.41 - 52; - 2008. - 6, №2 -C.86 - 94; - 2008. - 6, №3 -C.154 - 162; - 2012. - 10. №3 -C. 93 - 108; - 2012. -10. №4 -C. 61 - 90; - 2013. - 11. №2 - C. 46 - 50 .

Suvorova Iryna. Developing the theoretical foundations of system optimization for addressing effectively energy security issues to ensure the strategy of Europe's integrated and sustainable development. Paper presented at the Special Forum \& Exhibition on BEST OF EAST - FOR EASTERN PARTNERSHIP. November 28-30, 2011 WARSAW, Poland. ${ }^{\text {th }}$ International FORUM Science \& Technology Days Poland-East.

Попович I. $\Lambda$. Стреслімітуючий аАаптогенний механізм біологічної та Аікувальної активності води Нафтуся. Монографія. - К.: Видавничий Аім "Комп’ютерпрес", 2011. - 300 с.

\section{Translating References into English:}

Nikolay Suvorov and Irina Suvorova. Scientific basics of forming human quality and perfection to ensure holistic sustained development. European Journal of Sustainable Development (2015), 4, 1, 149 160. Doi: 10.14207/ejsd.2015.v4n1p149. ISSN: 2239-5938.

Suvorov N.P. A $\rho \imath \sigma \tau \sigma \varsigma \alpha v \theta \rho \omega \pi \sigma \varsigma$ - The perfect man. - M.: E.RA 2014. - 304p.

Suvorov N.P. Signals into systems of channels formation and wired communication. Textbook, Publisher Kharkov Higher Military School. NI Krylov, 1979. - 144p.

Suvorov N.P. System of channels formation and wired communications. Textbook, Publisher USSR Ministry of Defense, 1991. - 412p.

Suvorov N.P., Suvorova I.G. Introduction to Cosmotheory. Part I - VII. - Kharkov: Publishing Shust A.I., 2001, 2002, 2003. - 172p.

Suvorov N.P. Harmonic analysis as a way of human cognition// Medical Hydrology and Rehabilitation. 2003. - 1, №2 - P.100 -107; - 2004. - 2, №1 - P.91-102; - 2004. - 2, №2 - P.70 -79; - 2008. - 6, №4 - P.109 - 118; - 2009. - 7, №1 - P.103 - 109; - 2009. - 7, №4 - P.111 - 124; 2010. - 8, №1 - P.24 - 30; - 2010. - 8, №4 - P.73 - 78.

Suvorov N.P., Suvorova I.G. The Cosmotheory conceptions//Medical Hydrology and Rehabilitation. . 2004. - 2, №3 - P.58 -73; - 2004. - 2, №4 - P.84 - 95; - 2005. - 3, №1 - P.81 - 96; - 2005. 3, №3 - P.63 - 87; - 2007. - 5, №1 - P.41 - 52; - 2008. - 6, №2 - P.86 - 94; - 2008. - 6, №3 - P.154 - 162; - 2012. - 10. №3 - P. 93 - 108; - 2012. -10. №4 - P. 61 - 90; - 2013. 11. №2 - P. $46-50$. 
Suvorova Iryna. Developing the theoretical foundations of system optimization for addressing effectively energy security issues to ensure the strategy of Europe's integrated and sustainable development. Paper presented at the Special Forum \& Exhibition on BEST OF EAST - FOR EASTERN PARTNERSHIP. November 28-30, 2011 WARSAW, Poland. 5th International FORUM Science \& Technology Days Poland-East.

Popovich I.L. Streslimituyuchyy adaptogenic mechanisms of biological and therapeutic activity of water NAFTUSA. Monograph. - K.: Publishing House "Computerpress", 2011. - 300p. 